\title{
FOLIAR APPLICATION OF SALICYLIC ACID AND GIBBERELLIC ACID ENHANCES GROWTH AND FLOWERING OF Ixora coccinea $\mathbf{L}$. PLANTS \\ Gad, M.M.; E.Y. Abdul-Hafeez and O.H.M. Ibrahim** \\ Ornamental Plants and Landscape Gardening Department, Faculty of Agriculture, Assiut University, Assiut, Egypt. \\ *Corresponding author, Mobile: 00201100834843, e-mail: omer_hooo@yahoo.com, omer.ibrahim@agr.au.edu.eg
}

\begin{abstract}
Foliar application effects of salicylic acid (SA) and gibberellic acid $\left(\mathrm{GA}_{3}\right)$ were investigated on growth and flowering of Ixora coccinea L. plants. Four concentrations $(100,200,300$ and $400 \mathrm{ppm})$ of both SA and $\mathrm{GA}_{3}$ were sprayed in addition to the control (water-sprayed plants). Results indicated that all growth and flowering characteristics of Ixora plants were increased by all concentrations of $\mathrm{SA}$ or $\mathrm{GA}_{3}$ compared to the untreated plants. Concerning salicylic acid, the lowest concentration (100 ppm) produced the highest plants while $200 \mathrm{ppm}$ increased leaf area and shoot/root ratio. Number of leaves and plant pigments (chlorophyll a, b, a+b and carotenoids) were increased at 300ppm concentration. Spraying the plants with 400ppm increased fresh and dry weight of shoots and roots and flower number. $\mathrm{GA}_{3}$ sprayers at 300 or $400 \mathrm{ppm}$ led to a significant increase in most of the characteristics studied in comparison to the untreated plants. The correlation coefficient among most of Ixora vegetative and flowering growth characteristics proved to be significant.
\end{abstract}

Keywords: Ixora coccinea; flowering plants; growth regulators; gibberellin; plant hormones.

\section{INTRODUCTION}

Ixora coccinea belongs to family Rubiaceae is cultivated throughout the tropics as an ornamental plant. Ixora belongs to shrubs and small trees distributed in the tropical and sub- tropical regions. They are beautiful garden plants grown for their cluster of flowers, various hues and evergreen foliage and known to possess anticarcinogens in them and prove to be an effective remedy against tuberculosis (Malathy and Pai, 1998). The common name "flame of woods" was given to this tropical plant because of its brilliant red flowers, which remains open for a long time, contrast with the glossy, dark green leaves. They grow well in acidic soil and can be raised by seeds and cuttings (Holttum and Enoch, 1991).

Growth regulators such as salicylic acid (SA) and gibberellic acid $\left(\mathrm{GA}_{3}\right)$ are usually used to regulate growth and flowering of ornamental flowering plants Salicylic acid (SA) is a phenolic compound of hormonal nature produced by plants and plays an important role in responses to several abiotic stresses and to pathogen attack (Noreen et al. 2009, Abdelaal, 2015). SA has also been studied for its effects on various physiological processes related to growth and development of plants under normal conditions (no stress). Among these effects are the induction of flowering in herbaceous species (Hegazi and El-Shrayi, 2007), stimulation of root development, stomatal closure and reduced transpiration (Singh and Usha, 2003), reversal of the effects of abscisic acid (Davies, 2004) and regulation of gravitropism (Hussein et al., 2007). The effect of SA as an endogenous regulator of flowering was demonstrated in a number of plant species belonging to different families (Hayat et al., 2007). In addition to regulate flowering time, SA also links defense responses and reproductive development (Martínez et al., 2004).

Gibberellins are a class of endogenous plant growth substances actively involved in the control of a number of key developmental processes including endosperm mobilization and stem elongation, as well as flower and fruit development (Huttly and Phillips, 1995) Plants subjected to exogenous application of gibberellins have been found to exhibit increased activities of carbonic anhydrase, nitrate reductase (Afroz et al., 2005), $\mathrm{CO}_{2}$ fixation and stomatal conductance (Bishnoi and Krishnamoorthy, 1992). Moreover, $\mathrm{GA}_{3}$ acts as a mediator for acclimation of plants to leaf canopy, stimulates leaf area expansion (Davies, 1995) and induces elongation and osmoregulation in internodes (Azuma et al., 1997) in addition to increasing dry matter and biomass production (Gupta and Datta, 2001) and greatly enhancing the sink potential (Ouzounidou and Ilias, 2005).

The main objective of the current study was to investigate the effects of salicylic acid and gibberellic acid and to determine the optimum concentration of each of them that gives the best growth and flowering of potted Ixora plants.

\section{MATERIALS AND METHODS}

The current experiment was conducted at the Experimental Farm of Ornamental Plants and Landscape Gardening Department, Faculty of Agriculture, Assiut University, Assiut, Egypt during 2012-2013 and 2013-2014 seasons to evaluate the influence of foliar application of salicylic acid (El-Nasr Co. for Intermediate Chemicals, Egypt (NCIC)) and $\mathrm{GA}_{3}$ (S.D. Fine-Chem Limited, India) on growth and flowering of Ixora coccinea L. plants. Uniform 9month old plants of Ixora. coccinea L. $(13 \pm 1 \mathrm{~cm}$ height and $10 \pm 1$ leaves) were planted on mid of February for the two seasons in $20 \mathrm{~cm}$ diameter plastic pots filled with about 4.51 of an equal mixture of peat moss (Floratorf Company) and perlite $(1: 1 \mathrm{v} / \mathrm{v})$. The Experiment was arranged in RCBD design and divided into three replicates with nine treatments; each treatment contained six pots. The concentrations used 
were control (water sprayed), 100, 200, 300 and 400 ppm of each of SA and $\mathrm{GA}_{3}$. Plants were foliar sprayed (till run off) four times at 3 weeks interval and the first treatment was applied two weeks after transplanting.

Data recorded were; plant height $(\mathrm{cm})$, branches number/plant, leaf number/plant, leaf area $\left(\mathrm{cm}^{2}\right)$ measured using Digital Image Analysis according to O'Neal et al. (2002), total leaf area/plant $\left(\mathrm{cm}^{2}\right)$, fresh and dry weights of both shoots and roots $(\mathrm{g})$, shoot/root ratio, flower number/plant, florets number/flower and flower weight $(\mathrm{g})$. Chlorophyll $\mathrm{a}, \mathrm{b}$, chlorophyll $\mathrm{a}+\mathrm{b}$ and carotenoids were calculated as $\mathrm{mg} / \mathrm{g}$ fw.

Chlorophyll a, b and carotenoids were determined according to the acetone incubation method described by Krishnan et al. (1996). Leaf samples (100 $\mathrm{mg}$ ) were placed in a graduated tube containing $25 \mathrm{ml}$ of $80 \%$ acetone and the chlorophyll was extracted without grinding and centrifugation, by incubating the leaf tissues into the solvent in a dark place at incubation temperatures of $4^{\circ} \pm 2^{\circ}$. The contents of the tubes were shaken occasionally to accelerate the pigments extraction. After 48 hours of incubation the extract liquid was filtered through glass wool to remove leaf pieces and transferred to another graduated tube. The liquid extract then was made up to a total volume of 25 $\mathrm{ml}$ with $80 \%$ acetone. The chlorophyll content was spectrophotometrically analysed, in a UV visible spectrophotometer (Optizen Pop, Mecasys - Korea) using $3 \mathrm{ml}$ sealed quartz-glass cuvettes with a path length of $1 \mathrm{~cm}$. The chlorophyll content was calculated as $\mathrm{mg} / \mathrm{g}$ fw following the equations cited in Dere et al. (1998);

Table (1). Effect of $\mathrm{SA}$ and $\mathrm{GA}_{3}$ at different concentrations on some vegetative characteristics of Ixora coccinea L. plants during 2012/2013 $\left(1^{\text {st }}\right)$ and 2013/2014 $\left(2^{\text {nd }}\right)$ seasons.

\begin{tabular}{|c|c|c|c|c|c|c|c|c|c|c|c|}
\hline \multirow[t]{2}{*}{ Treatments } & \multirow{2}{*}{$\begin{array}{l}\text { Conc. } \\
\text { (ppm) }\end{array}$} & \multicolumn{2}{|c|}{$\begin{array}{l}\text { Plant height } \\
(\mathrm{cm})\end{array}$} & \multicolumn{2}{|c|}{$\begin{array}{c}\text { Branch } \\
\text { number/plant }\end{array}$} & \multicolumn{2}{|c|}{$\begin{array}{c}\text { Leaf } \\
\text { number/plant }\end{array}$} & \multicolumn{2}{|c|}{$\begin{array}{c}\text { leaf area } \\
\left(\mathrm{cm}^{2}\right)\end{array}$} & \multicolumn{2}{|c|}{$\begin{array}{c}\text { Total leaf area/plant } \\
\left(\mathrm{cm}^{2}\right)\end{array}$} \\
\hline & & $1^{\text {st }}$ & $2^{\text {nd }}$ & $1^{\text {st }}$ & $2^{\text {nd }}$ & $\mathbf{1}^{\text {st }}$ & $2^{\text {nd }}$ & $1^{\text {st }}$ & $2^{\text {nd }}$ & $1^{\text {st }}$ & $2^{\text {nd }}$ \\
\hline \multicolumn{2}{|c|}{ Control } & $38.25 \mathrm{e}$ & $39.17 \mathrm{c}$ & $1.33 \mathrm{~b}$ & $2.50 \mathrm{a}$ & $34.58 \mathrm{~d}$ & $46.42 \mathrm{c}$ & $12.55 \mathrm{c}$ & $12.20 \mathrm{~d}$ & 434.18 & 566.14 \\
\hline \multirow{4}{*}{ SA } & 100 & $52.00 \mathrm{bc}$ & $48.92 \mathrm{~b}$ & $1.42 \mathrm{~b}$ & $2.42 \mathrm{a}$ & $37.75 \mathrm{~cd}$ & $51.58 \mathrm{c}$ & $17.63 \mathrm{~b}$ & $19.17 \mathrm{abc}$ & 665.70 & 988.80 \\
\hline & 200 & $43.83 \mathrm{cde}$ & $47.42 \mathrm{~b}$ & $1.50 \mathrm{~b}$ & $2.92 \mathrm{a}$ & $43.83 \mathrm{bc}$ & $53.17 \mathrm{c}$ & $22.74 \mathrm{a}$ & $23.26 \mathrm{a}$ & 996.72 & 1236.51 \\
\hline & 300 & $43.50 \mathrm{cde}$ & $41.67 \mathrm{bc}$ & $1.67 \mathrm{~b}$ & $3.08 \mathrm{a}$ & $44.00 \mathrm{bc}$ & $56.83 \mathrm{bc}$ & $19.75 \mathrm{ab}$ & $20.68 \mathrm{abc}$ & 869.13 & 1175.06 \\
\hline & 400 & $43.08 \mathrm{de}$ & $41.50 \mathrm{bc}$ & $1.50 \mathrm{~b}$ & $3.00 \mathrm{a}$ & $43.50 \mathrm{bc}$ & $53.75 \mathrm{c}$ & $19.31 \mathrm{ab}$ & $19.53 \mathrm{abc}$ & 840.02 & 1049.62 \\
\hline \multirow{4}{*}{$\mathrm{GA}_{3}$} & 100 & $43.67 \mathrm{cde}$ & $70.08 \mathrm{a}$ & $1.42 \mathrm{~b}$ & $50 \mathrm{a}$ & $36.25 \mathrm{~cd}$ & $71.33 \mathrm{ab}$ & $12.58 \mathrm{c}$ & $16.41 \mathrm{bcd}$ & 455.91 & 1170.79 \\
\hline & 200 & $49.50 \mathrm{bcd}$ & $72.33 \mathrm{a}$ & $2.42 \mathrm{a}$ & $2.92 \mathrm{a}$ & $47.00 \mathrm{ab}$ & $74.00 \mathrm{a}$ & $15.78 \mathrm{bc}$ & $16.93 \mathrm{bcd}$ & 741.58 & 1252.93 \\
\hline & 300 & $55.17 \mathrm{ab}$ & $74.25 \mathrm{a}$ & $2.67 \mathrm{a}$ & $3.17 \mathrm{a}$ & $50.92 \mathrm{ab}$ & $75.58 \mathrm{a}$ & $15.64 \mathrm{bc}$ & $16.18 \mathrm{~cd}$ & 796.49 & 1222.57 \\
\hline & 400 & $61.58 \mathrm{a}$ & $75.42 \mathrm{a}$ & $2.92 \mathrm{a}$ & $3.08 \mathrm{a}$ & $51.92 \mathrm{a}$ & $81.08 \mathrm{a}$ & $17.37 \mathrm{~b}$ & $21.46 \mathrm{ab}$ & 901.97 & 1739.93 \\
\hline
\end{tabular}

* Means within the same column followed by different letters are significantly different $(\mathbf{P} \leq \mathbf{0 . 0 5})$ based on LSD.

Data presented in Table (2) show that spraying Ixora plants with $\mathrm{GA}_{3}$ promoted shoot fresh and dry weights, but root fresh and dry weights were enhanced by the application of SA. Increasing the concentration of either SA or $\mathrm{GA}_{3}$ led to a significant increase in Ixora plant fresh and dry weights. Plants treated with the highest concentration of $\mathrm{GA}_{3}(400 \mathrm{ppm})$ were
Chlorophyll $\mathrm{a}=11.75 \mathrm{~A}_{662}-2.350 \mathrm{~A}_{645}$

Chlorophyll $\mathrm{b}=18.61 \mathrm{~A}_{645}-3.960 \mathrm{~A}_{662}$

Carotenoids $=1000 \mathrm{~A}_{470}-2.270$ Chlorophyll a -81.4

Chlorophyll b/227

Data were subjected to the statistical analysis using " $F$ " test. Means were compared using the least significant differences (LSD) test at 5\% level of probability according to Gomez and Gomez (1984).

\section{RESULTS}

\section{Vegetative characteristics:}

The foliar application of either $\mathrm{SA}$ or $\mathrm{GA}_{3}$ proved significantly superior to the control (water sprayed plants) concerning all vegetative growth characteristics of Ixora plants as shown in Table (1). $\mathrm{GA}_{3}$-treated plants showed generally better growth than SA treatments. The highest concentration of $\mathrm{GA}_{3}(400$ ppm) gave the tallest plants $(61.58$ and $75.42 \mathrm{~cm})$, branch number (2.92 and 3.08) and leaf number (51.92 and 81.08) during both seasons, respectively.

SA at 200ppm increased leaf area recording the highest values $\left(22.74\right.$ and $23.26 \mathrm{~cm}^{2}$ during booth seasons, respectively) and total leaf area during the first season only $\left(996.72 \mathrm{~cm}^{2}\right)$ and recorded 81 and $91 \%$ in leaf area higher than the control during both seasons, respectively. On the other hand, a significant reduction in plant height was found in most cases as the concentration of SA was increased, where plant treated with 100 ppm SA were 36 and $25 \%$ taller than the untreated plants in both seasons, respectively 
Table (2). Effect of SA and $\mathrm{GA}_{3}$ at different concentrations on shoot and root fresh and dry weights of Ixora coccinea $\mathrm{L}$. plants during $2012 / 2013\left(1^{\text {st }}\right)$ and $2013 / 2014\left(2^{\text {nd }}\right)$ seasons.

\begin{tabular}{|c|c|c|c|c|c|c|c|c|c|c|c|}
\hline \multirow[t]{2}{*}{ Treatments } & \multirow{2}{*}{$\begin{array}{l}\text { Conc. } \\
\text { (ppm) }\end{array}$} & \multicolumn{2}{|c|}{$\begin{array}{c}\text { Shoot fw } \\
(\mathrm{g})\end{array}$} & \multicolumn{2}{|c|}{$\begin{array}{c}\text { Shoot DW } \\
\text { g }\end{array}$} & \multicolumn{2}{|c|}{$\begin{array}{c}\text { Root FW } \\
\text { g }\end{array}$} & \multicolumn{2}{|c|}{$\begin{array}{c}\text { Root DW } \\
\text { g }\end{array}$} & \multicolumn{2}{|c|}{$\begin{array}{l}\text { Shoot/Root } \\
\text { ratio }\end{array}$} \\
\hline & & $1^{\text {st }}$ & $2^{\text {nd }}$ & $1^{\text {st }}$ & $2^{\text {nd }}$ & $1^{\text {st }}$ & $2^{\text {nd }}$ & 1 $^{\text {st }}$ & $2^{\text {nd }}$ & $1^{\text {st }}$ & $2^{\text {nd }}$ \\
\hline \multicolumn{2}{|c|}{ Control } & $12.78 \mathrm{e}$ & $18.67 \mathrm{e}$ & $3.41 \mathrm{f}$ & $5.25 \mathrm{~g}$ & $9.38 \mathrm{e}$ & $16.00 \mathrm{~d}$ & $2.33 \mathrm{f}$ & $3.58 \mathrm{f}$ & 1.47 & 1.47 \\
\hline \multirow{4}{*}{ SA } & 100 & $17.33 \mathrm{~d}$ & $26.67 \mathrm{~d}$ & $5.98 \mathrm{~d}$ & $9.21 \mathrm{e}$ & $11.48 \mathrm{~d}$ & $17.67 \mathrm{~cd}$ & $3.35 \mathrm{e}$ & $5.15 \mathrm{e}$ & 1.79 & 1.79 \\
\hline & 200 & $17.92 \mathrm{~cd}$ & $27.00 \mathrm{~cd}$ & $7.46 \mathrm{~b}$ & $11.47 \mathrm{c}$ & $12.57 \mathrm{~cd}$ & $19.33 \mathrm{bcd}$ & $3.77 \mathrm{~cd}$ & $5.80 \mathrm{~cd}$ & 2.00 & 2.00 \\
\hline & 300 & $20.37 \mathrm{bc}$ & $31.33 \mathrm{~b}$ & $7.57 \mathrm{~b}$ & $11.65 \mathrm{c}$ & $14.52 \mathrm{ab}$ & $22.33 \mathrm{ab}$ & $4.47 \mathrm{~b}$ & $6.88 \mathrm{~b}$ & 1.70 & 1.70 \\
\hline & 400 & $21.67 \mathrm{~b}$ & $33.33 \mathrm{~b}$ & $9.72 \mathrm{a}$ & $14.96 \mathrm{~b}$ & $15.18 \mathrm{a}$ & $25.33 \mathrm{a}$ & $4.94 \mathrm{a}$ & $7.60 \mathrm{a}$ & 1.97 & 1.97 \\
\hline \multirow{4}{*}{$\mathrm{GA}_{3}$} & 100 & $18.35 \mathrm{~cd}$ & $29.67 \mathrm{bcd}$ & $4.96 \mathrm{e}$ & $7.64 \mathrm{f}$ & $13.00 \mathrm{bcd}$ & $20.00 \mathrm{bc}$ & $3.29 \mathrm{e}$ & $5.06 \mathrm{e}$ & 1.51 & 1.51 \\
\hline & 200 & $19.50 \mathrm{bcd}$ & $30.00 \mathrm{bcd}$ & $5.98 \mathrm{~d}$ & $9.20 \mathrm{e}$ & $13.22 \mathrm{bc}$ & $20.33 \mathrm{bc}$ & $3.47 \mathrm{de}$ & $5.33 \mathrm{de}$ & 1.73 & 1.73 \\
\hline & 300 & $20.15 \mathrm{bc}$ & $31.00 \mathrm{bc}$ & $6.68 \mathrm{c}$ & $10.27 \mathrm{~d}$ & $14.52 \mathrm{ab}$ & $22.33 \mathrm{ab}$ & $4.56 \mathrm{ab}$ & $7.02 \mathrm{ab}$ & 1.46 & 1.46 \\
\hline & 400 & $26.87 \mathrm{a}$ & $41.33 \mathrm{a}$ & $9.41 \mathrm{a}$ & $16.22 \mathrm{a}$ & $13.87 \mathrm{abc}$ & $21.33 \mathrm{~b}$ & $3.98 \mathrm{c}$ & $6.12 \mathrm{c}$ & 2.37 & 2.65 \\
\hline
\end{tabular}

* Means within the same column followed by different letters are significantly different $(\mathrm{P} \leq 0.05)$ based on LSD.

\section{Flowering characteristics}

As illustrated in Fig. (1). $\mathrm{GA}_{3}$ treatment at 400 ppm significantly increased flower number in the first season (7.67 flowers/plant) followed by SA at either 300 or $400 \mathrm{ppm}$. Adversely, SA at $400 \mathrm{ppm}$ produced 8.33 flowers/plant in the second season which was nonsignificantly superior to $400 \mathrm{ppm} \mathrm{GA}_{3} \quad(7.0$ flowers/plant). The highest floret number/flower was obtained in Ixora plants treated with either $\mathrm{GA}_{3}$ at either
$300 \mathrm{ppm}$ or SA at $400 \mathrm{ppm}$ in both seasons. The heaviest flower was noticed in plants treated with $\mathrm{GA}_{3}$ at $400 \mathrm{ppm}$ in both seasons (5.54 and $5.67 \mathrm{~g}$, respectively) which was non-significantly followed by 300 ppm $\mathrm{GA}_{3}$ (4.62 and $4.69 \mathrm{~g}$, respectively). The differences between $300 \mathrm{ppm} \mathrm{GA}_{3}$ and the other treatments including the control were proved nonsignificant.
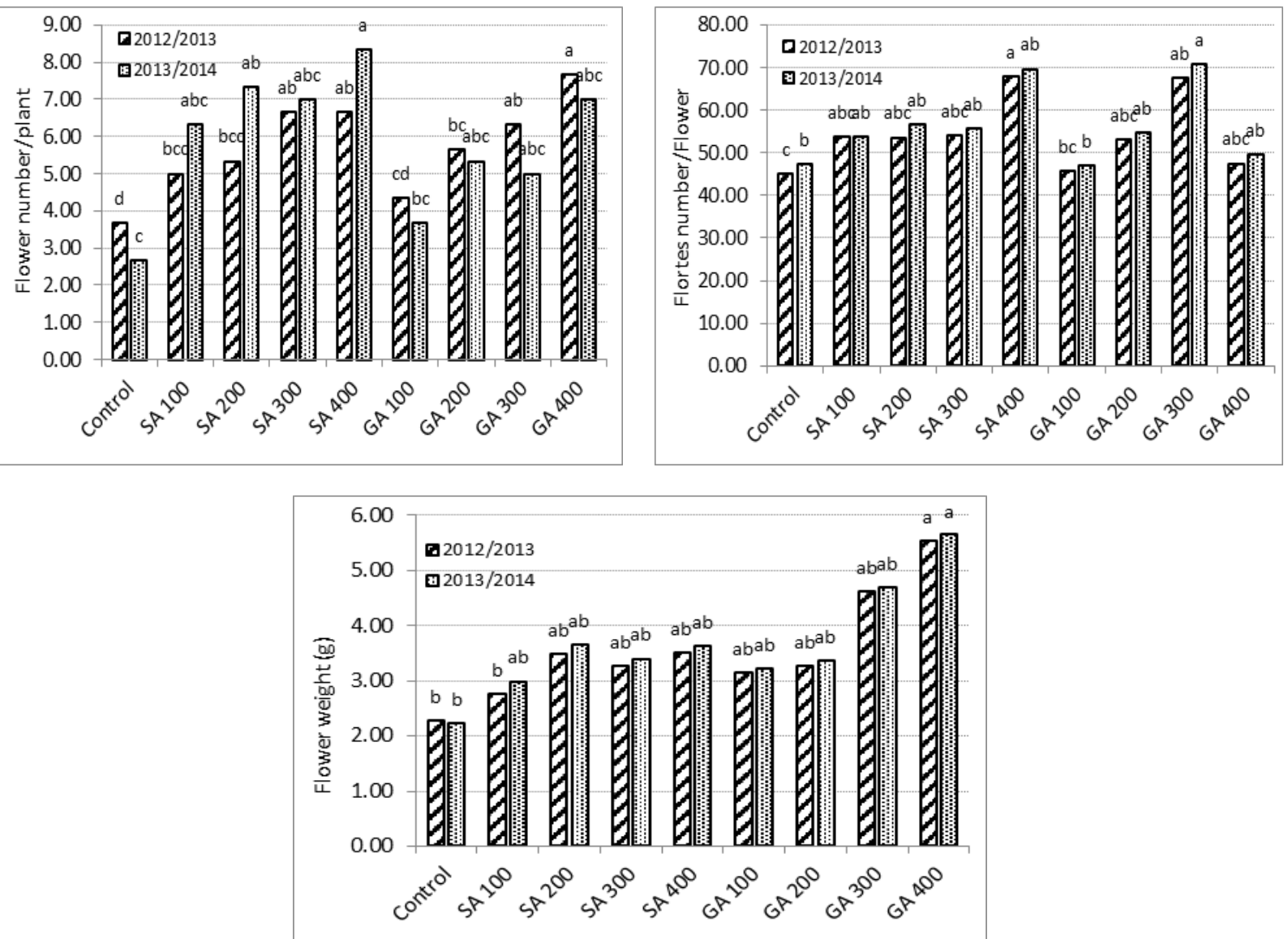

Fig 1. Effect of SA and $\mathrm{GA}_{3}$ at different concentrations on flower characteristics of Ixora coccinea $\mathrm{L}$. plants during 2012/2013 and 2013/2014 seasons. 


\section{Leaf pigments content}

It was observed that SA at $300 \mathrm{ppm}$ concentration showed higher chlorophyll a, b and carotenoids contents than the other concentrations (Table 3). The increment in chlorophyll a was approximately 52 and $37 \%$ in both seasons, respectively comparing to the control. These values were $58 \& 53 \%$ for chlorophyll $\mathrm{b}$ and $18 \& 23 \%$ for carotenoids. Concerning $\mathrm{GA}_{3}$, only chlorophyll a was significantly increased at 300 and $400 \mathrm{ppm}$ during the second season.

Table (3). Effect of $\mathrm{SA}$ and $\mathrm{GA}_{3}$ at different concentrations on leaf pigments content of Ixora coccinea $\mathrm{L}$. plants during 2012/2013 $\left(1^{\text {st }}\right)$ and $2013 / 2014\left(2^{\text {nd }}\right)$ seasons.

\begin{tabular}{|c|c|c|c|c|c|c|c|c|c|}
\hline \multirow[t]{2}{*}{ Treatments } & \multirow{2}{*}{$\begin{array}{l}\text { Conc. } \\
\text { (ppm) }\end{array}$} & \multicolumn{2}{|c|}{$\begin{array}{c}\text { Chlorophyll a } \\
\text { (mg/g fw) }\end{array}$} & \multicolumn{2}{|c|}{$\begin{array}{c}\text { Chlorophyll b } \\
\text { (mg/g fw) }\end{array}$} & \multicolumn{2}{|c|}{$\begin{array}{c}\text { Chlorophyll } \\
\text { a+b }\end{array}$} & \multicolumn{2}{|c|}{$\begin{array}{c}\text { Carotenoids } \\
(\mathrm{mg} / \mathrm{g} \text { fw })\end{array}$} \\
\hline & & $1^{\text {st }}$ & $2^{\text {nd }}$ & $1^{\text {st }}$ & $2^{\text {nd }}$ & $\mathbf{1}^{\text {st }}$ & $2^{\text {nd }}$ & $\mathbf{1}^{\mathrm{st}}$ & $2^{\text {nd }}$ \\
\hline \multicolumn{2}{|c|}{ Control } & $0.226 \mathrm{c}$ & $0.243 \mathrm{c}$ & $0.081 \mathrm{~b}$ & $0.079 \mathrm{~b}$ & 0.307 & 0.322 & $0.165 \mathrm{abc}$ & $0.152 \mathrm{bc}$ \\
\hline \multirow{4}{*}{ SA } & 100 & $0.302 \mathrm{ab}$ & $0.290 \mathrm{ab}$ & $0.114 \mathrm{ab}$ & $0.101 \mathrm{ab}$ & 0.417 & 0.391 & $0.199 \mathrm{a}$ & $0.179 \mathrm{ab}$ \\
\hline & 200 & $0.309 \mathrm{ab}$ & $0.304 \mathrm{a}$ & $0.100 \mathrm{ab}$ & $0.100 \mathrm{ab}$ & 0.409 & 0.403 & $0.171 \mathrm{abc}$ & $0.171 \mathrm{ab}$ \\
\hline & 300 & $0.343 \mathrm{a}$ & $0.332 \mathrm{a}$ & $0.128 \mathrm{a}$ & $0.121 \mathrm{a}$ & 0.471 & 0.453 & $0.194 \mathrm{ab}$ & $0.187 \mathrm{a}$ \\
\hline & 400 & $0.285 \mathrm{abc}$ & $0.310 \mathrm{a}$ & $0.093 \mathrm{~b}$ & $0.108 \mathrm{a}$ & 0.378 & 0.418 & $0.158 \mathrm{abc}$ & $0.179 \mathrm{ab}$ \\
\hline \multirow{4}{*}{$\mathrm{GA}_{3}$} & 100 & $0.228 \mathrm{c}$ & $0.260 \mathrm{bc}$ & $0.105 \mathrm{ab}$ & $0.108 \mathrm{ab}$ & 0.333 & 0.368 & $0.172 \mathrm{abc}$ & $0.178 \mathrm{ab}$ \\
\hline & 200 & $0.259 \mathrm{bc}$ & $0.261 \mathrm{bc}$ & $0.098 \mathrm{ab}$ & $0.102 \mathrm{ab}$ & 0.357 & 0.363 & $0.136 \mathrm{c}$ & $0.137 \mathrm{c}$ \\
\hline & 300 & $0.282 \mathrm{abc}$ & $0.303 \mathrm{ab}$ & $0.110 \mathrm{ab}$ & $0.107 \mathrm{ab}$ & 0.391 & 0.410 & $0.149 \mathrm{bc}$ & $0.152 \mathrm{bc}$ \\
\hline & 400 & $0.286 \mathrm{abc}$ & $0.316 \mathrm{a}$ & $0.092 \mathrm{~b}$ & $0.099 \mathrm{ab}$ & 0.379 & 0.416 & $0.134 \mathrm{c}$ & $0.138 \mathrm{c}$ \\
\hline
\end{tabular}

* Means within the same column followed by different letters are significantly different (P $\leq 0.05)$ based on LSD.

\section{The correlation coefficients matrix}

The correlation matrix presented in Table (4) revealed significant correlation coefficient values at $\mathrm{p} \leq 0.05$ among most of Ixora vegetative growth and flowering characteristics. Among the most obvious significant correlations are that between flower number/plant and each of shoot dry weight $(r=0.73 \&$ $0.54)$, root dry weight $(r=0.65 \& 0.38)$ in both seasons, respectively. Chlorophyll a was significantly correlated with shoot dry weight ( $\mathrm{r}=0.46 \& 0.65)$, root dry weight $(r=0.49 \& 0.54)$ and leaf area $(r=0.42 \& 0.41)$ in both seasons, respectively. Meanwhile, carotenoids negatively and significantly correlated with plant height in both seasons $(r=-0.49 \&-0.46)$.

\section{DISCUSSION}

The current experiment proved that growth and flowering of Ixora plant could be improved by the application of either $\mathrm{SA}$ or $\mathrm{GA}_{3}$. The highest concentration of $\mathrm{GA}_{3}(400 \mathrm{ppm})$ resulted in the highest values of plant height, branch number, leaf number, leaf area/plant, fresh and dry weights of shoots, shoot-root ratio, flower number and weight in addition to high leaf content of chlorophyll $\mathrm{a}$ and $\mathrm{b}$. The positive correlation among most of these characteristics as indicated in Table (4) could explain the enhancement in overall growth obtained by the $\mathrm{GA}_{3}$ at $400 \mathrm{ppm}$. For example flower number, as an important characteristic of Ixora plant, is positively and significantly correlated with all vegetative and biomass characteristics in addition to leaf content of chlorophyll a. The percentage of the variation in the flower number/ plant was accounted for by the linear function of the aforementioned growth characteristics as could be calculated through the equation [100 (r) $\left.{ }^{2}\right]$ (Gomez and Gomez 1984). The positive variation in flower number/plant reaching 25 , $16,32,59,53$ and $22 \%$ is accounted for by the positive linear function of plant height, branch number, leaf number, shoot fresh weight, shoot dry weight and leaf content of chlorophyll a, respectively.

The favorable effect of $\mathrm{GA}_{3}$ foliar application on plant growth has been reported previously by several investigators. $\mathrm{GA}_{3}$ was found to improve the whole plant growth (Davies et al., 2009), plant height, stem elongation, leaf expansion and flower development (Davies, 1995), plant dry mass, leaf area, plant growth rate and crop growth rate (Khan et al. 2002), flowering (Asil et al., 2011). An explanation of the significant increase in plant height in $\mathrm{GA}_{3}$-treated plants could be the growth promotion effect of $\mathrm{GA}_{3}$ in stimulating and accelerating cell division, increasing cell elongation and enlargement, or both (Hartmann et al., 1990). Other investigators indicated the involvement of $\mathrm{GA}_{3}$ in cell elongation such as Ohkawa (1979). Flowering promotion by $\mathrm{GA}_{3}$ could be also interpreted upon its effect on enhancing photosynthetic activity (Kim and Miller, 2009). The role of $\mathrm{GA}_{3}$ in inducing the net photosynthetic rate, stomatal conductance, and chlorophyll concentration could explain its positive effect on plant growth and flowering.

$\mathrm{GA}_{3}$ resulted in a moderate root fresh and dry values comparing to $\mathrm{SA}$. This is supported by the findings of Aftab et al. (2011) who reported nonsignificant effect of $\mathrm{GA}_{3}$ on total biomass of the plants. The treatments of SA proved superior to $\mathrm{GA}_{3}$ treatments regarding leaf area, fresh and dry weight of roots and leaf content of chlorophyll a. Plants treated with SA at $200 \mathrm{ppm}$ were characterized by the widest leaves which were non-significantly different for those treated with the higher concentrations (300 and 400 ppm).

The heaviest fresh and dry roots and the highest leaf content of chlorophyll a were found in plants sprayed with SA at either 300 or 400 ppm with nonsignificant differences in between. SA improved Ixora flowering characteristics as well. The highest values of flower number/plant, floret number/flower and flower weight were shared between $\mathrm{SA}$ at $400 \mathrm{ppm}$ and $\mathrm{GA}_{3}$ at $400 \mathrm{ppm}$. A significant correlation confident was found 
between both leaf area and root dry weight which were both significantly enhanced by SA treatments. Approximately $20 \%$ of positive variation in leaf area is accounted for by the positive linear function of root dry weight. The correlation coefficient was also significant between chlorophyll a and each of leaf area and fresh and dry weight of shoots and roots. All these facts proved the highly positive effect of SA in boosting Ixora plant photosynthesis which is directly reflected on plant vegetative, flowering and biomass characteristics. These results are in accordance with those obtained by several previous investigators such as
Nagasubramaniam et al. (2007) who found that leaf area, crop growth rate and total dry matter production in baby corn were increased by the application of SA (7.2 $\times 10^{-4}$ ). The effect of SA on improving plant dry mass was also revealed by Singh and Usha (2003). Jeyakumar et al. (2008) reported also an enhancement in dry matter production in black gram by the treatment of SA $\left(10^{-4}\right.$ $\mathrm{M})$. They also found an effect on plant height and shoot and root dry weights. Foliar application of salicylic acid increased the leaf area of sugarcane as found by Zhou et al. (1999).

Table (4). Correlation coefficients matrix (r) of growth characteristics of Ixora coccinea L. plants as affected by the foliar application of $\mathrm{SA}$ and $\mathrm{GA}_{3}$ at different concentrations during $2012 / 2013\left(1^{\text {st }}\right)$ and 2013/2014 $\left(2^{\text {nd }}\right)$ seasons.

\begin{tabular}{|c|c|c|c|c|c|c|c|c|c|c|c|c|c|c|}
\hline Characteristics & Season & 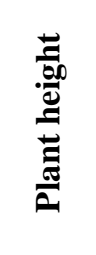 & 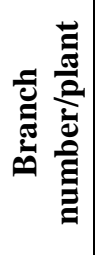 & 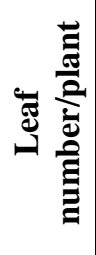 & & $\frac{\vec{z}}{\stackrel{0}{\circ}}$ & 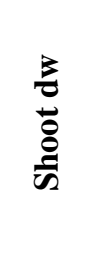 & $\frac{z}{\mathscr{8}}$ & 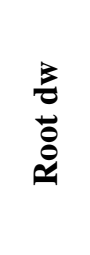 & 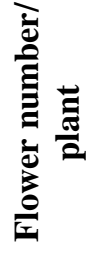 & 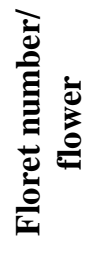 & 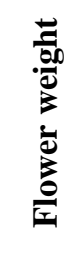 & 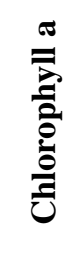 & $\frac{e}{\bar{z}}$ \\
\hline \multirow{2}{*}{$\begin{array}{l}\text { Branch } \\
\text { number/plant }\end{array}$} & $1^{\mathrm{st}}$ & $0.65 *$ & - & - & - & - & - & - & - & - & - & - & - & - \\
\hline & $2^{\text {nd }}$ & 0.03 & - & - & - & - & - & - & - & - & - & - & - & - \\
\hline \multirow{2}{*}{$\begin{array}{l}\text { Leaf } \\
\text { number/plant }\end{array}$} & $1^{\mathrm{st}}$ & $0.53 *$ & $0.82 *$ & - & - & - & - & - & - & - & - & - & - & - \\
\hline & $2^{\text {nd }}$ & $0.79 *$ & $0.43 *$ & - & - & - & - & - & - & - & - & - & - & - \\
\hline \multirow{2}{*}{ Leaf area } & $1^{\mathrm{st}}$ & 0.06 & -0.10 & 0.25 & - & - & - & - & - & - & - & - & - & - \\
\hline & $2^{\text {nd }}$ & 0.09 & 0.06 & 0.09 & - & - & - & - & - & - & - & - & - & - \\
\hline \multirow{2}{*}{ Shoot fw } & $1^{\mathrm{st}}$ & $0.58 *$ & $0.53 *$ & $0.66^{*}$ & 0.32 & - & - & - & - & - & - & - & - & - \\
\hline & $2^{\text {nd }}$ & $0.46^{*}$ & 0.36 & $0.51 *$ & $0.41 *$ & - & - & - & - & - & - & - & - & - \\
\hline \multirow{2}{*}{ Shoot dw } & $1^{\mathrm{st}}$ & 0.37 & 0.34 & $0.57 *$ & $0.54 *$ & $0.77 *$ & - & - & - & - & - & - & - & - \\
\hline & $2^{\text {nd }}$ & 0.11 & 0.33 & 0.24 & $0.60^{*}$ & $0.80 *$ & - & - & - & - & - & - & - & - \\
\hline \multirow{2}{*}{ Root fw } & $1^{\mathrm{st}}$ & 0.29 & $0.42 *$ & $0.57 *$ & 0.31 & $0.66^{*}$ & $0.67 *$ & - & - & - & - & - & - & - \\
\hline & $2^{\text {nd }}$ & 0.14 & 0.24 & 0.15 & 0.35 & $0.54 *$ & $0.63 *$ & - & - & - & - & - & - & - \\
\hline \multirow{2}{*}{ Root dw } & $1^{\mathrm{st}}$ & 0.21 & 0.27 & $0.56^{*}$ & $0.46^{*}$ & $0.61^{*}$ & $0.80 *$ & $0.78^{*}$ & - & - & - & - & - & - \\
\hline & $2^{\text {nd }}$ & 0.07 & $0.39 *$ & 0.19 & $0.45^{*}$ & $0.60 *$ & $0.74 *$ & $0.77 *$ & - & - & - & - & - & - \\
\hline \multirow{2}{*}{$\begin{array}{l}\text { Flower number/ } \\
\text { plant }\end{array}$} & $1^{\mathrm{st}}$ & $0.50 *$ & $0.40 *$ & $0.57 *$ & $0.44 *$ & $0.77 *$ & $0.73^{*}$ & $0.64 *$ & $0.65 *$ & - & - & - & - & - \\
\hline & $2^{\text {nd }}$ & -0.07 & -0.01 & -0.07 & 0.35 & 0.36 & $0.54 *$ & 0.27 & $0.38 *$ & - & - & - & - & - \\
\hline \multirow{2}{*}{$\begin{array}{l}\text { Floret number/ } \\
\text { flower }\end{array}$} & $1^{\mathrm{st}}$ & 0.13 & 0.04 & 0.14 & 0.13 & 0.08 & 0.31 & 0.29 & $0.41 *$ & 0.07 & - & - & - & - \\
\hline & $2^{\text {nd }}$ & -0.07 & 0.02 & -0.11 & -0.10 & 0.06 & 0.25 & $0.43 *$ & $0.41 *$ & $0.47 *$ & - & - & - & - \\
\hline \multirow{2}{*}{ Flower weight } & $1^{\text {st }}$ & $0.48^{*}$ & 0.35 & $0.38^{*}$ & 0.12 & $0.40^{*}$ & 0.31 & 0.31 & 0.22 & 0.18 & 0.26 & - & - & - \\
\hline & $2^{\text {nd }}$ & 0.16 & $0.54 *$ & $0.45 *$ & -0.05 & $0.40^{*}$ & $0.41^{*}$ & 0.29 & 0.24 & 0.08 & 0.23 & - & - & - \\
\hline \multirow{2}{*}{ Chlorophyll a } & $1^{\text {st }}$ & 0.18 & 0.05 & 0.24 & $0.42 *$ & 0.19 & $0.46^{*}$ & 0.37 & $0.49 *$ & 0.31 & 0.18 & -0.09 & - & - \\
\hline & $2^{\text {nd }}$ & -0.15 & 0.28 & -0.04 & $0.41^{*}$ & $0.42 *$ & $0.65^{*}$ & $0.49 *$ & $0.54 *$ & $0.47 *$ & 0.34 & $0.48^{*}$ & - & - \\
\hline \multirow{2}{*}{ Chlorophyll b } & $1^{\mathrm{st}}$ & 0.06 & -0.03 & -0.002 & 0.004 & -0.05 & 0.06 & 0.18 & 0.27 & -0.002 & 0.01 & -0.13 & $0.67 *$ & - \\
\hline & $2^{\text {nd }}$ & -0.01 & 0.32 & 0.17 & 0.23 & 0.25 & 0.33 & 0.36 & $0.45^{*}$ & 0.17 & 0.21 & 0.36 & $0.68 *$ & - \\
\hline \multirow{2}{*}{ Carotenoids } & $1^{\mathrm{st}}$ & $-0.49 *$ & $-0.41 *$ & -0.25 & 0.17 & -0.29 & -0.15 & -0.23 & -0.05 & -0.28 & 0.10 & -0.32 & 0.08 & 0.17 \\
\hline & $2^{\text {nd }}$ & $-0.46^{*}$ & 0.10 & -0.35 & 0.15 & -0.06 & -0.01 & -0.02 & 0.21 & 0.21 & -0.06 & -0.19 & 0.09 & 0.20 \\
\hline
\end{tabular}

To interpret these results, the effect of SA on plant functions should be understood. SA is involved in regulating plant growth processes as reported by previous studies such as Singh (1993) who demonstrated the effect of SA in stimulating of root formation in young shoots of ornamental plants. Spraying SA at the flowering stages of cotton increased boll numbers as shown by Hampton and Oosterhuis (1990). This positive effect could be explained upon the effect of SA on increasing $\mathrm{CO} 2$ assimilation and accordingly photosynthetic rate in addition to the increase in mineral uptake (Karlidage et al. 2009). Another explanation for the positive effect of SA on growth and yield could be its influence on other plant hormones which play a fundamental role in the auxin, cytokinin and ABA balances (Shakirova, 2007).

The current experiment showed a significant increase in plant height in SA-treated plants over the control treatment. Nagasubramaniam et al. (2007) demonstrated that SA treatments increased plant height 
comparing to the control. Increasing the concentration of SA in our experiment resulted in a significant decrease in plant height. This reduction in plant height with the higher concentrations of SA was clearly compensated by a significant increase in leaf area and plant fresh and dry biomass. These results are supported by the findings of Pancheva et al. (1996) who reported that growth of barley seedling leaves and roots decreased when plants were treated with SA, with a stronger effect observed when the concentration of SA was increased.

\section{CONCLUSIONS}

The enhancement of vegetative and flowering growth characteristics of Ixora, as an amazing flowering pot plant, was induced by the foliar application of either $\mathrm{SA}$ or $\mathrm{GA}_{3}$. Four concentrations from each of $\mathrm{SA}$ and $\mathrm{GA}_{3}$ were used in the current experiment, the best of which were 400 ppm $\mathrm{GA}_{3}$ and 300 or 400 ppm of SA. In general, $\mathrm{GA}_{3}$ was superior in improving growth and flowering quality of Ixora. Accordingly, to get more compact plants bearing bigger leaves and high quality flowers to be sued as pot plants, it's advised to spray Ixora plants with SA at either 300 or 400 ppm. Meanwhile, to produce plants with taller shoots useful for getting more cuttings, in addition to more flowers with high quality, $\mathrm{GA}_{3}$ at $400 \mathrm{ppm}$ is recommended.

\section{REFERENCES}

Abdelaal Kh. A. A. (2015) Effect of salicylic acid and abscisic acid on morpho-physiological and anatomical characters of faba bean plants (Vicia faba L.) under drought stress. J. Plant Production, Mansoura Univ., 6 (11): 1771 - 1788.

Afroz S.; Mohammad F.; Hayat S. and Siddiqui M. (2005) Exogeneous application of gibberellic acid counteracts the ill effects of sodium chloride in mustard. Turk J Biol, 29: 233-236

Aftab T.; Khan M.M.A.; Idrees Mohd and Naeem M Moinuddin (2011) Optimizing nitrogen levels combined with gibberellic acid for enhanced yield, photosynthetic attributes, enzyme activities, and artemisinin content of Artemisia annua. Front Agric China, 5: 51-59. Doi: 10.1007/s11703-011-1065-7

Asil M.H.; Roein Z. and Abbasi J. (2011) Response of tuberose (Polianthes tuberose L.) to gibberellic acid and benzyladenine. Hort. Environ. Biotechnol., 52: 46-51

Azuma I.; Ueno S.; Uchid N. and Yasuda I. (1997) Gibberellin induced elongation and osmoregulation in internodes of floating rice. Physiol. Plant, 99: 517-522. Doi:10.1111/j.13993054.1997.tb05351.x

Bishnoi N.R. and Krishnamoorthy H.N. (1992) Effect of waterlogging and gibberellic acid on leaf gasexchange in peanut (Arachis hypogaea L.). J Plant Physiol, 139: 503-505. Doi:10.1016/S01761617(11)80502-X
Davies M.J.; Atkinson C.J.; Burns C.; Woolley J.G.; Hipps N.A.; Arroo R.R.J.; Dungey N.; Robinson T.; Brown P.; Flockart I.; Hill C.; Smith L. and Bentley S. (2009) Enhancement of artemisinin concentration and yield in response to optimization of nitrogen and potassium supply to Artemisia annua. Ann Bot, 104: 315-323. Doi:10.1093/aob/mcp126

Davies P.J. (2004) Plant hormones: Their nature, occurrence and functions. In: Davies PJ (ed) Plant Hormones: Biosynthesis, Signal Transduction, Action, Kluwer Academic Publishers, London, p1-15

Davies P.J. (1995) Plant Hormones: Physiology, Biochemistry and Molecular Biology. Kluwer Academic Publishers, Dordrecht, the Netherlands

Dere S.; Gunes T. and Sivaci R. (1998) Spectrophotometric determination of chlorophyll - $\mathrm{a}, \mathrm{b}$ and total carotenoid contents of some algae species using different solvents. Tr J of Botany, 22: $13-17$

Gomez K.A. and Gomez A.A. (1984) Statistical Procedures for Agricultural Research. $2^{\text {nd }}$ edn. John Wily, NY, 680 pp

Gupta V.N. and Datta S.K. (2001) Influence of gibberellic acid on growth and flowering in chrysanthemum (Chrysanthemum morifolium Ramat) cv. Jayanti. Indian J Plant Physiol, 6: 420-422

Hampton R.E. and Oosterhuis D.M. (1990) Application of phenolic acids to manipulate boll distribution in cotton. Arkansas Farm Res, 39: 11-18

Hartmann H.T.; Kester D.E. and Davies FTJr. (1990) Plant Propagation, Principles, and Practices. $5^{\text {th }}$ edn. Prentice-Hall, Englewood Cliffs, NJ

Hayat S.; Ali B. and Ahmad A. (2007) Salicylic acid: biosynthesis, metabolism and physiological role in plants. In: Hayat S, Ahmad A (eds) Salicylic Acid: A Plant Hormone, Springer, Dordrecht, The Netherlands, p: 1-14

Hegazi A.M. and El-Shrayi A.M. (2007) Impact of salicylic acid and paclobutrazol exogenous application on the growth, yield and nodule formation of common bean. Aust J Basic Appl Sci 1: $834-840$

Holttum R.E. and Enoch I. (1991) Gardening in the Tropics. Times Publications, Singapore, p: 134-137

Hussein M.M.; Balbaa L.K. and Gaballah M.S. (2007) Salicylic acid and salinity effects on growth of maize plants. Res J Agric Biol Sci, 3: 321-328

Huttly A.K. and Phillips A.L. (1995) Gibberellin regulated plant gene. Physiol Plant, 95: 310-317

Jeyakumar P.; Velu G.; Rajendran C.; Amutha R.; Savery M.A.J.R. and Chidambaram S. (2008) Varied responses of black gram (Vigna mungo) to certain foliar applied chemicals and plant growth regulators. Legume Res Int J, 31: 110-113

Karlidag H.; Yildirim E. and Turan M. (2009) Salicylic acid ameliorates the adverse effect of salt stress on strawberry. Sci Agric, 66: 180-187. Doi:10.1590/S0103-90162009000200006 
Khan N.A.; Mir R.; Khan M.; Javid S. and Samiulla H. (2002) Effects of gibberellic acid spray on nitrogen yield efficiency of mustard grown with different nitrogen levels. J Plant Growth Regul, 38: 243-247

Kim H.J.; Miller W.B. (2009) $\mathrm{GA}_{4+7}$ plus BA enhance post-production quality in pot tulips. Postharvest Biol Technol 51: 272-277

Krishnan P.; Ravi I. and Nayak S.K. (1996) Methods for determining leaf chlorophyll content of rice: A reappraisal. Indian Journal of Experimental Biology, 34: 1030-1033

Malathy S. and Pai J.S. (1998) In vitro propropagation of Ixora singporensis. Curr Sci, 75: 545-547

Martínez C.; Pons E.; Prats G. and León J. (2004) Salicylic acid regulates flowering time and links defence responses and reproductive development. Plant J, 37: 209-217. Doi:10.1046/j.1365313X.2003.01954.X

Nagasubramaniam A; Pathmanabhan G. and Mallika V (2007) Studies on improving production potential of baby corn with foliar spray of plant growth regulators. Ann Rev Plant Physiol Plant Mol Biol, 21: 154-157

Noreen S.; Ashraf M.; Hussain M. and Jamil A. (2009) Exogenous application of salicylic acid enhances antioxidative capacity in salt stressed sunflower (Helianthus annus L.) plants. Pakistan J Bot, 41: 473-479

O'neal M.E.; Landis D.A. and Isaacs R. (2002) An inexpensive, accurate method for measuring leaf area and defoliation through digital image analysis. Field and Forage Crops, 95: 1190-1194. Doi:10.1603/0022-0493-95.6.1190
Ohkawa K. (1979) Effects of gibberellins and benzylandenine on dormancy and flowering of Lilium speciosum. Scientia Horticulturae, 10: 255-260. Doi: 10.1016/0304-4238(79)90080-3

Ouzounidou G. and Ilias I. (2005) Hormone-induced protection of sunflower photosynthetic apparatus against copper toxicity. Biol Plant, 49: 223-228. Doi: 10.1007/s 10535-005-3228-y

Pancheva T.V.; Popova L.P. and Uzunova A.M. (1996) Effect of salicylic acid on growth and photosynthesis in barley plants. J Plant Physiol, 149: 57-63. Doi: 10.1016/S01761617(96)80173-8

Shakirova F.M. (2007) Role of hormonal system in the manisfestation of growth promoting and antistress action of salicylic acid. In: Hayat S. and Ahmad A (eds) Salicylic Acid, A Plant Hormone, Springer, Dordrecht, Netherlands, p:69-90. Doi:10.1007/1-4020-5184-0

Singh B. and Usha K. (2003) Salicylic acid-induced physiological and biochemical changes in wheat seedlings under water stress. Plant Growth Regul, 39: 137-141. Doi:10.1023/A:1022556103536

Singh S.P. (1993) Effect of non-auxinic chemicals on root formation in some ornamental plant cuttings. Adv Hortic For, 3: 207-210

Zhou X.M.; Mackeuzie A.F.; Madramootoo C.A. and Smith D.L.J. (1999) Effects of some injected plant growth regulators with or without sucrose on grain production biomass and photosynthetic activity of field-grown corn plants. Agro Crop Sci, 183: 103-110

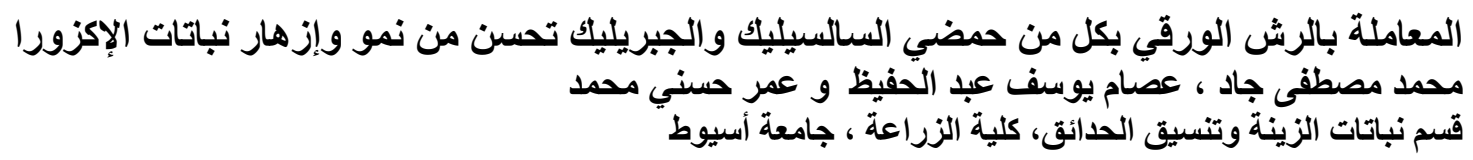

تهدف التجربة الحالية إلى اختبار نأثير المعاملة بالرش الورقي بكل من حمضي السالسيليك و الجبريليك على نمو و إزهـار نباتـات

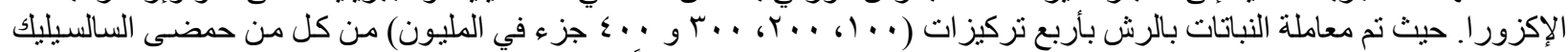

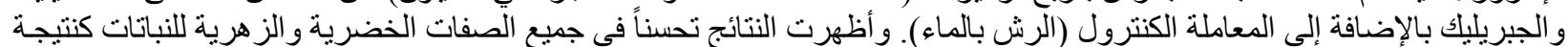

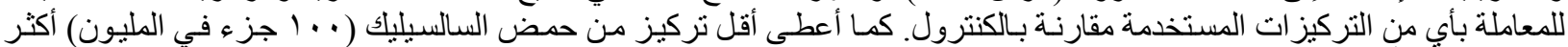

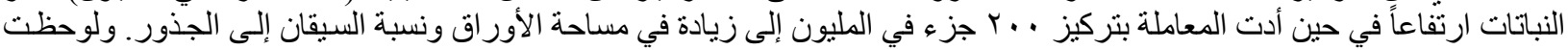

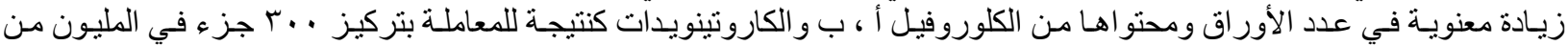

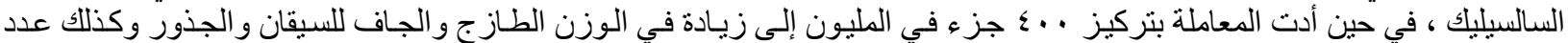

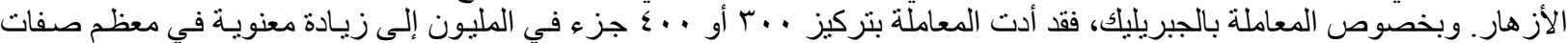

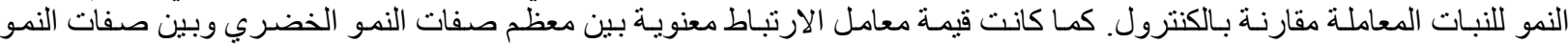
الزهري للنباتات. 